\title{
Contrasting Romance and Turkish as Source Languages: Evidence from Borrowing Verbs in Modern Greek Dialects
}

\author{
Angela Ralli \\ Emeritus Professor of Linguistics, Department of Philology, School of \\ Humanities, University of Patras, Patras, Greece \\ ralli@upatras.gr
}

\begin{abstract}
In this paper, I deal with verb borrowing in a language-contact situation involving Greek as target and Romance and Turkish as source languages. More particularly, I discuss the reasons and techniques that make verbs of typologically and genetically different languages to be accommodated in a uniform way within the same linguistic system, and verbs of the same donor to be integrated in a different manner within the same recipient. I try to provide an explanation for the observed divergences and similarities by appealing to an interplay of linguistic and extra-linguistic factors. For the purposes of this study, evidence is drawn from both written and oral sources from five Greek dialectal varieties: Grekanico, Heptanesian, Pontic, Aivaliot and Cypriot.
\end{abstract}

\section{Keywords}

verb borrowing - integration - Modern Greek dialects - Romance - Turkish 
Contact between languages, triggered by socio-political, economic and cultural relations, is, among other things, the cause of linguistic innovations due to matter and pattern replication. ${ }^{1}$ Contact phenomena have attracted the interest of scholars in recent years, who try to describe and analyze them from different perspectives and various theoretical frameworks, as well as to establish the principles constraining the influence of the source on the target languages.

Greek, ${ }^{2}$ throughout its long history, shows an interesting diversity of these phenomena, which is particularly witnessed on the dialectal level, since the current official language, that is, Standard Modern Greek, is not the real outcome of the evolution of Ancient Greek: Standard Modern Greek has been primarily based on Peloponnesian, the dialect spoken at the time of the formation of the first Greek state (1827), contains few elements of the prestigious dialects of the Ionian islands (see Fig. 1) and Constantinople (today's Istanbul), and during the last two centuries, it has been enriched with words and expressions

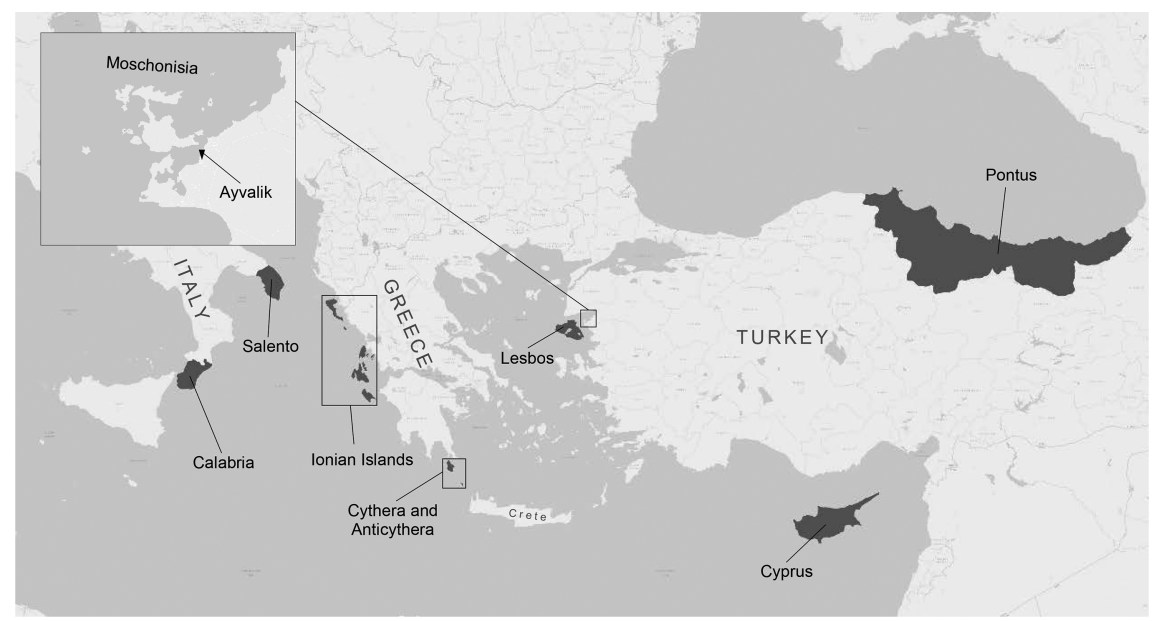

FIGURE 1: Areas where the dialects examined in this article are spoken.

1 The terms "matter" and "pattern replication" for lexical and structural borrowing are due to Sakel (2007). See Gardani (2020a) for a typology on matter and pattern borrowing which goes beyond morphology.

2 In this article, "Greek" is used as a roof term referring to the language throughout its history. The other terms, "Ancient Greek" (fifth - fourth century вСЕ), "Hellenistic Koine" (ca. third century BCE - third century CE), "Modern Greek" (after the fifteenth century CE) and "Standard Modern Greek" (the current official language) refer to the linguistic systems of specific periods. 
from Katharevousa, a high-style written language form, created for political purposes in the nineteenth century. Contact phenomena emerge in all Modern Greek dialects, the origin of which is usually considered to be the Hellenistic Koine, ${ }^{3}$ and are observed on multiple linguistic levels - lexical, grammatical, phonological, semantic - and in heterogeneous communicative contexts. They are detected in the existing dialectal texts and in various oral narratives that have been collected in the last two centuries. Significantly, in the dialect geography of Modern Greek, two antithetical developments, divergence and convergence, produce changes in areas which have been under the influence of different languages.

In this article, I investigate five Greek dialects, Grekanico, Heptanesian, Pontic, Aivaliot and Cypriot, with the aim to determine phenomena and unexplored paths produced by contact between Greek and two genetically and typologically different languages, Romance on one side and Turkish on the other, depending on the case.

My purpose is to examine why in a contact situation involving Greek as target language and two different source languages, both genetically and typologically (Romance is Indo-European and semi-fusional while Turkish is Altaic and agglutinative), can produce not only divergent but also similar effects in Greek, which are mostly shown on lexical borrowing, identified as the commonest and most frequent type of transfer in contact situations (Haspelmath, 2009), and the morphological structure of the borrowed elements. More precisely, I focus on the domain of verbal loans that are usually considered to be among the most difficult items to be transferred from one language to another, due to the rich information they carry (see Wohlgemuth, 2009 for details). In contrast, nouns are generally seen as the easiest borrowable grammatical category (Whitney, 1881; Hock and Joseph, 1996), ${ }^{4}$ due to their referential properties as Matras (2009: 168 ) sustains. $^{5}$

In this work, I restrict my attention to the transfer of verbs, excluding other parts of speech (e.g., nouns), which have become verbs in the Greek dialects with the addition of a verbalizer. I try to investigate four general questions

3 Tsakonian is an exception, since for many scholars (see for instance Deffner, 1881), it derives from the Ancient Doric dialect.

4 A stronger view is expressed by Moravcsik (1978: 111), who claims that "verbs cannot be borrowed as such but must be borrowed as nouns and 'reverbalized' in the borrowing language".

5 Another explanation could be drawn from Seifart et al. (2018), who have observed a crosslinguistic tendency for slower speech before nouns, compared to speech occurring before verbs, defined in terms of pauses and slower articulation. While these authors do not account for lexical borrowing, one could argue that this property makes nouns easier to isolate and as a consequence to borrow. I owe this remark to Francesco Gardani (p.c.). 
referring to: (a) the role of the source and the target languages; (b) the mechanisms and paths involved in verb borrowing and adaptation; (c) the factors and principles regulating the degree and type of verb integration; (d) the constraints applying to the occurrence of an integrating element.

The examined data are drawn from both written and oral sources. Among the written sources, there are available dictionaries, glossaries and grammars, such as: Karanastasis $(1984 ; 1997)$ and Rohlfs $(1933 ; 1977)$ for Grekanico, Soldatos (1967), Katsouda (2016) and Simiris (2017) for Heptanesian, Papadopoulos (1955: 1958-1961) and Oikonomidis (1958) for Pontic, Sakkaris (1940; 1948) and Ralli (2017) for Aivaliot, and Chatziioannou (1936) and Chatzipieris and Kapatas (2015) for Cypriot. The oral data are drawn from a digitized corpus consisting of about 200 hours of oral narratives, stored at the Laboratory of Modern Greek Dialects (LMGD, https://www.lmgd.philology.upatras.gr) of the University of Patras.

The article is structured as follows: after the introduction, Section 2 contains a brief overview of Grekanico, Heptanesian, Pontic and Aivaliot, accompanied by an indicative list of loan verbs and a number of remarks on the properties shown by these loans. A discussion of the four research questions mentioned above is provided in Section 3, where tentative answers are proposed, and the interplay of endogenous and exogenous factors in verb integration is pointed out. The Cypriot data provided in Section 4 serves as a testing bed to hypotheses and proposals, put forward in Section 3. The article ends with the conclusions (Section 5) and the relevant bibliography.

\section{Dialects and Dialectal Data}

\subsection{Grekaniko}

The Greek speaking dialectal enclaves in South Italy are located in Puglia (area of Salento, the so-called "Grecia Salentina") and South Calabria (Bovese area), as depicted in Fig. 1. In this article, the Greek dialect of South Italy will be called "Grekanico", used as a roof term for Greko, the Greek variety of Calabria, and Griko, the Greek variety of Salento. Other roof terms found in the literature are "Italiot" (e.g., Ralli, 2016) or "South Italian Greek" (e.g., Manolessou and Ralli, 2020).

Due to the long-term Italo-Romance rule, Grekanico has been affected by the Southern Italo-Romance dialects (Salentino or Calabrese, depending on the case), the official Italian (mainly from the second half of the twentieth century onwards), and a form of Regional Italian (Martino, 1979; Profili, 1983; Katsoyannou, 1995; 1999; Fanciullo, 2001; Manolessou, 2005; Squillaci, 
2016). ${ }^{6}$ Nowadays, Greko presents a rapid decrease and Katsoyannou (1995) reported that in mid-nineties there were no more than 5 oo native speakers left in Calabria, while several villages were deserted. In contrast, Griko seems to be resisting, although native competence has been rather confined to elderly people. According to Profili (1983), there were about nine Griko-speaking villages in the early eighties, where speakers communicated in the dialect mostly in family. Details about the socio-linguistic situation in the Greek-speaking areas of South Italy are given, among others, in Profili (1983), Telmon (1992), Katsoyannou (1995), Manolessou (2005) and Squillaci (2016).

The origin of Grekanico is a debated issue, and arguments pertaining to the "archaism" or "byzantinism" of this dialect are of historical and linguistic nature (Fanciullo, 2001; Manolessou, 2005). There are three different views: (a) the dialect is of Byzantine origin (among others, Morosi, 1870; Parlangeli, 1953); (b) Grekanico originates from the Ancient Greek of Magna Graecia (among others, Rohlfs, 1933; 1977; 1997; Caratzas, 1958; and Karanastasis, 1984); (c) it descends from the Hellenistic Koine, while it has been enriched with byzantinisms, especially Griko, due to Byzantine settlers in the area (Horrocks, 1997; Ledgeway, 1998; Fanciullo, 2001; Browning, 2004; Manolessou, 2005).

Griko and Greko display a number of differences (see, among others, Rohlfs, 1933; Caracausi, 1979; Karanastasis, 1997; Squillaci, 2016). However, these differences are not significant in order to consider Griko and Greko as different dialectal systems. Crucially, there is no divergence in the way the two varieties adopt Italo-Romance verbs.

In this section, I list some indicative Griko and Greko examples under (1). ${ }^{7}$ All these examples as well as those of the other dialects are given in the citation form, that is, in the first person singular of the present tense (overtly realized infinitival forms have disappeared from Greek during the Hellenistic period, see Horrocks, 1997), and are transcribed in a broad phonological transcription. For clarity reasons, hyphens separate the stems from the verbalizer and inflection.

a.

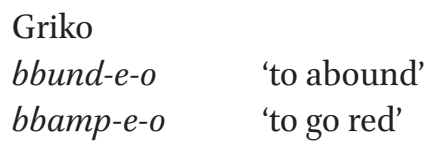

Salentino

$\operatorname{bbunn}(d)$-are

bbamp-are

6 For the contact between Greko and Italo-Romance, see also the article by Ledgeway, Schifano and Silvestri (2021) on the formation of negative imperative forms in Southern Calabrian.

7 The Griko examples are drawn from the oral narratives stored at LMGD, which were recorded in 200o, during a research expedition to Salento, under the direction of Angela Ralli (European Project INTERREG II). I owe the Greko examples to Maria Olimpia Squillaci. 


$\begin{array}{lll}\text { ffrunt-e-o } & \text { 'to confront' } & \text { ffrunt-are } \\ \text { kunt-e-o } & \text { 'to narrate' } & \text { kunt-are } \\ \text { mbest-e-o } & \text { 'to guess' } & \text { mbišt-ire } \\ \text { nat-e-o } & \text { 'to swim' } & \text { nat-are } \\ \text { skupr-e-o } & \text { 'to discover' } & \text { skupr-ire }\end{array}$

b. Greko

bbamp-eggu-o
nnat-eggu-o
pass-eggu-o
pens-eggu-o
spend-eggu-o

Calabrian

'to go red' bbamp-ari

'to swim' nnat-ari

'to pass' pass-ari

'to think' pens-ari

'to spend' spend-iri

As shown in (1), only the Italo-Romance stems are adopted by the Griko and Greko speakers, who hellenicize them with the use of an integrating element, the Greek verbalizer $-e(v)$. In Griko, /v/ is phonologically deleted in the intervocalic position (for this, see Karanastasis, 1997), while in Greko, -ev- appears as -eggu-, originating from -ev $\gamma$-with the insertion of a $/ \gamma /$, well known in other Modern Greek dialects too, e.g., in Cretan and Lesbian (Contossopoulos, 2001).

For Wichmann and Wohlgemuth (2008) and Wohlgemuth (2009), the accommodation of adopted verbs follows three insertion strategies, direct, indirect and light verb. For the direct strategy, the loan verb is plugged in the target language as it is, or with a slight phonological modification. The indirect strategy involves the presence of an integrating element - in the Grekanico case, the verbalizer $-e(v)--$, while a light verb is employed for the implementation of the third strategy. ${ }^{8}$

According to what is commonly assumed in the literature, for lexical borrowing, languages borrow entire words (Thomason, 2001; Winford, 2003; Matras, 2009). As shown in Section 3, I suppose that word forms are transferred to Grekanico. Then, the speakers analyze them, retain only the stem, add the Greek verbalizer $-e(v)$ - in order to produce a more hellenicized form, and the structure [stem + verbalizer] is further combined with the Greek inflectional endings.

\subsection{Heptanesian}

Heptanesian is the dialect of the Ionian islands including Corfu, Paxi, Cephalonia, Ithaca, Zante and the smaller islands of Othoni, Herikusa, Mathraki,

8 There is no application of the light-verb strategy to the integration of verbal loans in the dialects investigated in this article. 
Antipaxi, as well as Cythera and Anticythera south of the Peloponnese (Fig. 1. See, among others, Salvanos, 1918; Soldatos, 1967; Hitiris, 1987; Konomos, 2003; Katsouda, 2016; Simiris, 2017) ${ }^{9}$ Heptanesian displays several traits of ItaloRomance, that is, Venetian and Italian, due to the long-term domination of the islands by the Republic of Venice: the islands remained under Venetian rule from approximately the mid-fourteenth century (the exact dates vary, depending on the island ${ }^{10}$ ) until the turn of the nineteenth century, when they passed to British control, and ultimately to the Greek state in 1864 .

There are some linguistic differences from island to island, but not substantial enough to challenge the linguistic unity of Heptanesian, which can be seen as an umbrella term capturing the features that are shared by all varieties.

As far as the existing written sources are concerned, beside the literary works, one can locate a plethora of glossaries, excerpts of old magazines, manuscripts, fairytales, personal stories and memoirs, recipes, folk songs, proverbs, administrative documents and correspondence, collections of civil acts, ecclesiastical and educational records (see Makri, 2020 for a detailed list). There are several works reporting contact between Heptanesian and Italo-Romance, but with some exceptions (for example Ralli, 2012a; Katsouda, 2016; Simiris, 2017), they focus on nouns (see, among others, Hitiris, 1987; Kahane and Kahane, 1982; Korosidou-Karra, 2003; Ralli et al., 2015; Krimpas, 2018; Makri, 2020).

In what follows, I provide a number of Italo-Romance verbal loans (a hyphen separates stems from inflectional endings), taken from Ralli (2012a), Katsouda (2016) and Simiris (2017). ${ }^{11}$ It is worth mentioning that it is often difficult to discern whether a verb has been transferred from Venetian or Italian, because, as noted by Fanciullo (2008), there was a kind of diglossia in the Republic of Venice from the sixteenth century onwards, where Venetian was mainly employed in the everyday communication, while Italian for administrative purposes. This diglossic situation was also transferred to areas under Venetian rule, among which, the Ionian islands (Ralli, 2019a).

9 The inhabitants of Leukada, another big Ionian island, speak a dialect which shares similarities with the group of Northern Greek dialects, mainly due to the proximity of the island to the Greek mainland, but also because Leukada was under Venetian rule for a shorter period of time, as Venice conquered the island in 1664 (Contossopoulos, 2001: 67). For example, it displays the phenomena of high-vowel deletion and mid-vowel raising in unstressed position (see footnote ${ }^{17}$ for details).

10 Corfu underwent the Venetian domination as early as in 1387 , while the other Heptanesianspeaking islands were taken by Venice during the $15^{\text {th }}$ century.

11 In (2), the It(alian) origin is noted when a Venetian form is not attested in Boerio's (1856) and Cortelazzo's (2017) dictionaries of the Venetian dialect. 
(2) Heptanesian abandoner-o akompajar-o amolar-o arivar-o yoðer-o (i)bitsilir-o

(i)mitar-o kojonar-o krepar-o lustrar-o tratar-o vatsinar-o ${ }^{12}$

$\begin{array}{ll}\begin{array}{ll}\text { 'to abandon' } & \begin{array}{l}\text { Venetian } \\ \text { abandon-ar }\end{array} \\ \text { 'to accompany' } & \begin{array}{l}\text { acompagn-ar } \\ \text { 'to free' }\end{array} \\ \text { 'to arrive' } & \begin{array}{l}\text { ariv-ar } \\ \text { god-er }\end{array} \\ \text { 'to enjoy' } & \text { It. imbecill-ire } \\ \text { 'to render imbe- } \\ \text { cile' }\end{array} \\ \text { 'to imitate' } & \text { It. imit-are } \\ \text { 'to make fun of' } & \text { cogion-ar } \\ \text { 'to crack' } & \text { crep-ar } \\ \text { 'to shine' } & \text { lustr-ar } \\ \text { 'to serve' } & \text { trat-ar }\end{array}$

'to deal with, to treat'

A first examination of the Heptanesian verbal loanwords reveals that they are based on the entire Italo-Romance infinitival forms -they involve the infinitival marker -ar(e)- and appear to be fully integrated in the Heptanesian system, being regularly inflected with the addition of the Greek inflectional endings. ${ }^{13}$ This distinguishes them from the Grekanico loans, where no infinitival mark is part of the adopted Italo-Romance verb. Having adopted full-word forms, Heptanesian does not employ any specific integrating element, since, as stated by Wohlgemuth (2009: 87-92), the inflectional endings do not count as such, being compulsory in the recipient's system, as is the case with Greek morphology. Italo-Romance verbal loans in Heptanesian obey the direct insertion strategy, contrary to those in Grekanico (1), which follow the indirect insertion strategy. Thus, an interesting question which arises is why verbs of the same source language are integrated differently in the same target language.

\subsection{Pontic}

Pontic belongs to the inner Asia Minor dialectal group (Manolessou, 2019). It was spoken in a geographical area of about 400 kilometers (from Inepolis to Colchis) in the northeast part of Asia Minor (Black Sea coast of Turkey), and in

12 Francesco Gardani (p.c.) has pointed out that this must have been one of the latest Venetian loans, since vaccinus in its current meaning is not attested before the first decade of the nineteenth century.

13 Note that the same integration of Italo-Romance verbs is observed in other Modern Greek Dialects that have been in contact with Venetian, as for instance in the dialect of Crete (Chairetakis, 2020). 
parts of the inland of Asia Minor, 100 kilometers from the coast (Oikonomidis, 1958), as shown in Fig. 1. In the nineteenth century, a number of Pontic communities settled in Ukraine and Georgia, and a massive movement of Pontics, principally to mainland Greece, took place under the Lausanne Treaty (July 1923), which led to an exchange of Muslim and Christian Orthodox people between Greece and Turkey. Since then, the dialect has been used by second and/or third generation refugees in Greece (according to Drettas, 1997: 15, there are about 300,000 speakers), but can also be found in Georgia, Ukraine (Mariupol area) and in Rostov-on-Don of the Russian Federation (see, among others, Berikashvili, 2017). Moreover, a variety of Pontic is still spoken in certain dialectal enclaves in Turkey, namely in the Western part of Trebizond (Tonya, Sürmene and the valley of Of), by Muslim Pontics, who were exempted from the population exchange for religious reasons. Their dialect is usually called "Muslim Pontic" or simply "Romeyka" (Mackridge, 1987; Sitaridou, 2013; Özkan, 2013).

The Pontus area came under the Ottoman rule in 1461, but the Greekspeaking people resisted to massive islamization and shifting to Turkish (among others, Vryonis, 1971; Bryer, 1975; Kitromilides and Alexandris, 1984). According to Manolessou (2019: 34), there is a sufficient number of written sources in Pontic (see Henrich, 1990; 2011 for the Medieval Pontic texts), compared to the existing sources of other Modern Greek dialects.

Pontic is divided into Western and Eastern, the two varieties displaying some differences but also sharing striking similarities (see Papadopoulos, 1955 and Oikonomidis, 1958 for a detailed account of this division). The examples listed in (3) are taken from Papadopoulos (1958-1961) and from 30 hours oral sources, stored at LMGD. ${ }^{14}$ The Turkish examples are given in the $-m A k$ infinitival form, while the loan stems in Pontic are separated from the Greek/Pontic verbalizer $-e v$ - and the personal ending $-o$ (first person singular of the present tense).

$\begin{array}{llll}\text { Pontic } & & \text { Turkish } & \\ \text { xazirla-ev-o } & \text { 'to prepare' } & \text { hazırla-mak } & \text { 'to get ready'15 } \\ \text { tokun-ev-o } & \text { 'to insult' } & \text { dokun-mak } & \\ \text { ta }(\gamma) \text { ut-ev-o } & \text { 'to scatter/disperse' } & \text { dağtt-mak } & \\ \text { razan-ev-o } & \text { 'to earn' } & \text { kazan-mak } & \\ \text { axtar-ev-o } & \text { 'to overturn/transfer' } & \\ & & & \end{array}$

14 The oral material was collected under the direction of Angela Ralli, within the framework of the THALIS project (2012-2015), funded by ESF and the Greek Ministry of Education.

15 The Turkish original word is translated only when its meaning (slightly) differs from that in Pontic. 


\begin{tabular}{|c|c|c|}
\hline pašla-ev-o & 'to begin' & başla-mak \\
\hline yurtar-ev-o & 'to free/save' & kurtar-mak \\
\hline tajan-ev-o & 'to be patient' & dayan-mak \\
\hline konuš-ev-o & 'to talk' & konuş-mak \\
\hline pekle-ev-o & 'to wait' & bekle-mek \\
\hline šašir-ev-o & 'to be surprised' & şaşır-mak \\
\hline yantur-ev-o & 'to trick' & kandır- \\
\hline
\end{tabular}

These examples show that for adopting Turkish verbs, Pontic retains only the stem and applies the indirect insertion strategy with the use of the derivational suffix - ev-. It is worth stressing that Italo-Romance loans in Grekanico (1) follow the same path as Turkish loans in Pontic (3): both dialects adopt the stem from the source language (Italo-Romance or Turkish, depending on the dialect), and employ the same integrator, that is, the Greek verbalizer -ev-. Given the difference in the source language, that is, Turkish for Pontic and Italo-Romance for Grekanico, this is an interesting point that should be explored.

\subsection{Aivaliot}

Aivaliot, another Asia Minor dialect (Ralli, 2019b), was spoken until 1922, in the town of Kydonies or commonly Aivali (present day Ayvalık), on the Western coast of Turkey (Edremit gulf, four to five miles from the Aegean Greek island of Lesbos, see Fig. 1). A slightly different variety, Moschonisiot, was the language of the inhabitants of the nearby islands of Moschonisia (nowadays Cunda), while a variant of Aivaliot is still found on the Aegean Turkish island Bozcaada (Imbros in Greek). Before the First World War, Aivali had about 30,00o Greek-speaking residents, while Moschonisia counted circa 15,000 people. Moschonisia and Aivali were deserted from their Greek speaking population in September 1922, after the end of the Greek-Turkish war and several months before the Lausanne treaty. Aivaliots and Moschonisiots who escaped killing flew to Greece, principally to Lesbos, while a number of them moved to other countries as well, e.g., France, North America and Australia.

The dialect has originally emerged following a settlement of colonists from the island of Lesbos, around the late sixteenth or early seventeenth centuries. Today, there is an estimated number of few hundreds of Aivaliot speakers, descendants from first-generation refugees, most of them living in Lesbos, who often mix their own dialectal variety with the parent Lesbian. ${ }^{16}$

Aivaliot and Moschonisiot do not display significant differences to constitute different dialects. Thus, in this article, the term "Aivaliot" will be used for

16 See Sakkaris (1920) and Ralli (2019b) for a detailed history of the area and the dialect. 
both varieties. The dialect belongs to the group of Northern Greek dialects ${ }^{17}$ and has been heavily influenced by Turkish, mainly on the lexical and morphological levels (see Ralli, 2012a; 2016; 2019b; Ralli et al., 2015 for a detailed presentation). It has adopted many lexical items from Turkish, especially nouns and verbs. For verbs, as shown in (4) with the examples drawn from Ralli (2012b), the transferred item is not the infinitival form ending in - $m A k$, but the third person singular of the Turkish past tense ending in - $d I$ (given in parenthesis). ${ }^{18}$ Hyphens separate the loan items from an optional Greek verbalizer $-i z$ - and the compulsory inflectional suffix $-o$ or $-u$ (unstressed $-o$, as explained in footnote ${ }^{17}$ ).

(4) Aivaliot $^{19}$

burd-iz-u
dald-iz-u

kudurd-iz-u

kazad-iz-u/

kazad-ó

furlad-iz-u

zurlad-iz-u

katsird-iz-u /

katsird-ó

axtard-iz-u / 'to throw, over-

axtard-ó 'to be
(pej.) rich'

'to burn from anger'

'to twist'
'to be absent-
minded'

Turkish

bur-mak

dal-mak

(bur-du)

(dal-d $\iota)$ 'to dive, plunge'

'to earn, become kazan-mak (kazan-dı)

'to force, stretch'

firla-mak

(firla-dı)

'to dash, pop up'

zorla-mak (zorladı)

kaçır-mak (kaçırdı) 'take away,

aktar-mak (aktar-dı) kidnap' 'to transfer, mix'

17 The Modern Greek dialects are divided into northern and southern on the basis of a high-vowel loss and a mid-vowel raising in unstressed position (Chatzidakis, 1905-1907; Newton, 1972; Contossopoulos, 2001; Trudgill, 2003). For example, /fegári/ 'moon' becomes [figár], /xoráfi / 'field' [xuráf] and /kutí/ 'box' [kti].

18 In (4), the infinitival ending and the past tense (aorist) ending are noted with the capital letters A and I, respectively, because Turkish is subject to a vowel-harmony law, according to which in consecutive syllables, the vowel of the second syllable is changed conforming to the vowel of the preceding syllable. Thus, a verb like 'to love' has an infinitival form in -mek (sevmek), and a third person aorist form in -di (sevdi), while the corresponding forms of the verb 'to earn, profit' are kazanmak and kazandı. As a contact phenomenon, vowel harmony is observed in the Asia Minor Cappadocian dialect (Dawkins, 1916). However, it is not a transferred feature in Aivaliot and Pontic.

19 Stress appears on all Aivaliot verbs because of the Northern Greek vocalism which deletes unstressed /i/ and /u/ and raises unstressed /e/ and /o/ (see footnote ${ }^{17}$ for details). 


\begin{tabular}{|c|c|c|c|c|}
\hline $\begin{array}{l}\text { sacind-íz-u/ } \\
\text { sacind-ó }\end{array}$ & $\begin{array}{l}\text { 'to stand back/ } \\
\text { aside' }\end{array}$ & sakın-mak & $(s a k ı n-d \iota)$ & $\begin{array}{l}\text { 'beware, } \\
\text { avoid' }\end{array}$ \\
\hline dajad-ó & 'to bear, endure' & dayan-mak & (dayan-dı) & \\
\hline savurd-ó & 'to throw' & savur-mak & $($ savur-dı) & \\
\hline $\begin{array}{l}\text { sasird-íz-u / } \\
\text { sasird-ó }\end{array}$ & 'to be at a loss' & şaşır-mak & $(s ̧ a s ̧ \iota r-d \iota)$ & $\begin{array}{l}\text { 'to wonder, } \\
\text { be at a loss' }\end{array}$ \\
\hline
\end{tabular}

Similarly to all Greek native verbs, the loans receive inflection, with the addition of Greek inflectional endings. As mentioned in Section 2.2, the inflectional ending could not be considered as integrator, since its presence is compulsory in the recipient system, and its addition to the Turkish lexeme is done by default.

As opposed to Pontic (3), which also borrows Turkish verbs but retains only the stem, Aivaliot adopts the $-d I$ third person singular of the past tense and most of the times adds the Greek verbalizer - $i z$ - as integrating element, obeying the indirect insertion strategy. The particular choice of integrator is another difference with Pontic, where, as observed in (3), the integrator is -ev-. Moreover, contrary to the other three dialects, Aivaliot adopts Turkish verbs by following two insertion strategies which, in some cases, seem to function in parallel: the indirect strategy with the use of $-i z$-, and the direct one, without the presence of any verbalizer. The question is, thus, why there is such divergence, creating doublets in -dizu and -do (e.g., kazadízu / kazadó 'to earn'). ${ }^{20}$

Interestingly, the direct strategy has been attested in Heptanesian (2) with respect to Italo-Romance loans (e.g., trataro 'to treat' < Venetian tratar). However, the two dialects differ as far as the point of departure of the adopted material is concerned, in that, Heptanesian loans are transferred from the infinitival form, while the Aivaliot ones are based on a finite form (third person singular of the past tense), the latter being ultimately reanalyzed as stem in order to receive the optional Greek verbalizer - $i z$ - and the compulsory Greek inflectional suffix. One may wonder whether the type of the source language plays a role in this choice. Such role is debatable though, given the fact that for both Aivaliot and Pontic the source language is the same, that is, Turkish, but Pontic adopts only the verbal stem and hellenicizes it with the verbalizer $-e v$-, while Aivaliot keeps the entire form of the third person singular of the past tense and optionally uses the verbalizer $-i z$ -

20 It should be noted that, in Aivaliot, as well as in the other dialects examined in this article, there are verbs of Turkish or Italo-Romance origin which may display a different derivational suffix, for instance -on-. However, these loans are derived structures on the basis of other parts of speech, for example nouns (e.g., Aivaliot batakónu 'sink in the mud' < Turkish batak 'swamp, mud' + Greek verbalizer -on- + Greek 1SG), and do not belong to direct verb transfer. Thus, they are excluded from my investigation. 
On the basis of what has been seen so far, the overall typology of the source language, that is, semi-fusional or agglutinative, does not seem to determine the strategy and the pattern that are followed for adopting and accommodating verbs, as well as the choice of a particular integrating element. According to the "anything goes" position (among others, Thomason, 2001), anything can be borrowed as long as there is heavy socio-cultural contact. In fact, the long-term Italo-Romance or Turkish domination of the lands where the four dialects are/were spoken could justify the abundance of borrowed verbs. However, the extra-linguistic factors alone are not sufficient to explain the specific way of verb accommodation. Thus, although socio-linguistics play an important role in verb borrowing and integration, additional reasons must be searched in the linguistic factors, more particularly in the linguistic properties of the languages in contact.

As proposed by Ralli (2005; 2015), Greek is a stem-based language, where an inflectional ending is obligatorily added to nominal and verbal stems in order for them to become inflected words. That is, inflected words obey the $[[$ Stem-(Der) $]$-Infl] structural pattern, where the stem can be derived or non-derived. This property is crucial for the borrowing of nominal and verbal items, since, with the only exception of a small amount of English and French borrowed nouns (see Ralli and Makri, 2020), the adopted elements are treated as stems, undergo small phonological adjustments dictated by the Greek phonological system, and are ultimately combined with overt Greek inflectional suffixes, while some of them include a derivational suffix too. For an illustration, see the examples in $\left(5^{-8}\right)$, taken from the dialects under investigation, where only Pontic and Grekanico seem to select the bare stem. All the other items are adopted from Italo-Romance and Turkish as word forms, which are further reanalyzed as stems.

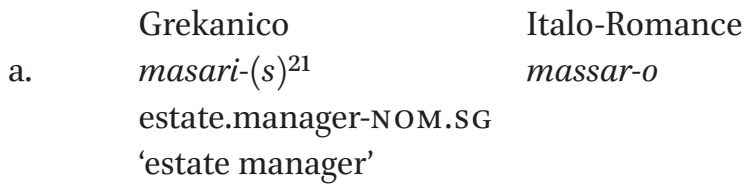

21 The final -s of the nominative singular (citation form) is deleted because Grekanico, influenced by Italo-Romance, does not allow closed syllables at the end of words. See Karanastasis (1997) and Manolessou and Ralli (2020) for details. 
b.

$\begin{array}{ll}\text { čec-e-o }{ }^{22} & \text { čik-are } \\ \text { to blind-DER-1SG } & \text { 'to blind' }\end{array}$

(6)

'I blind'

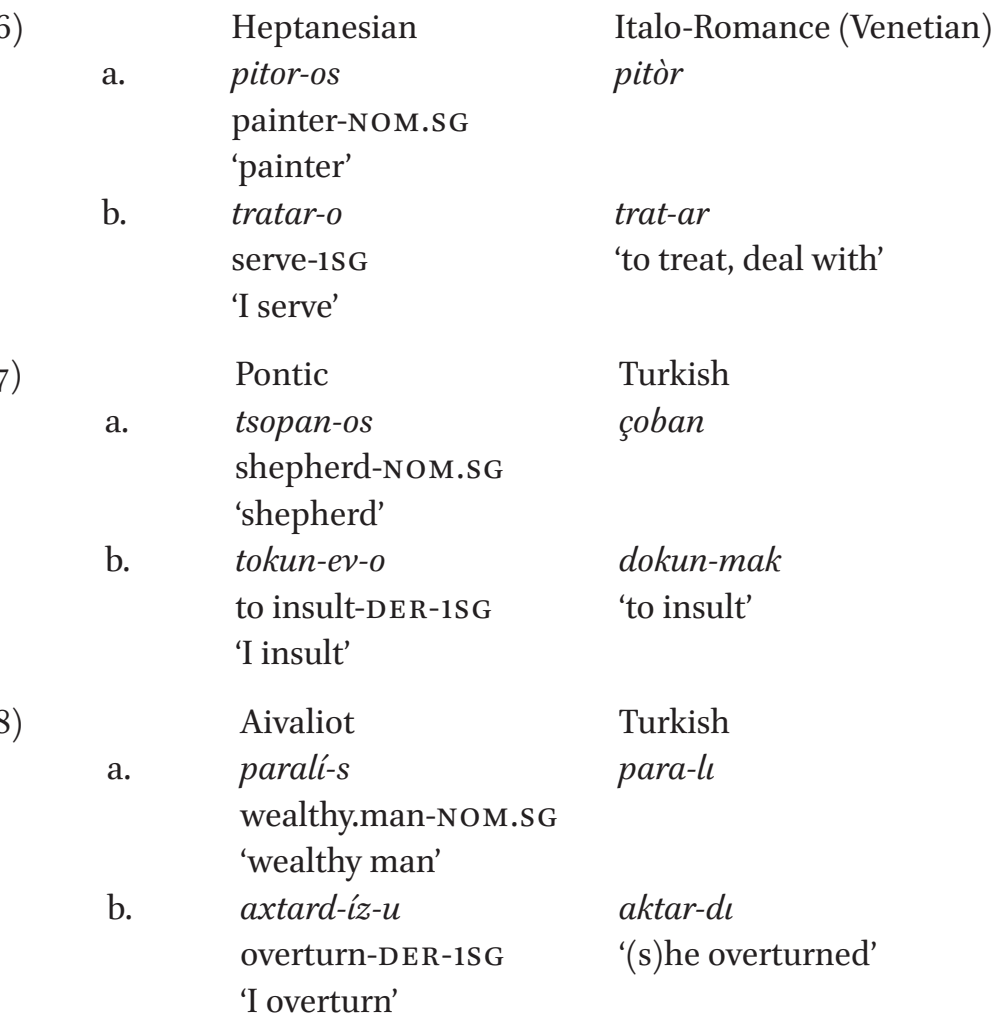

Ralli (2005; 2015) has shown that the stem-based property of Greek morphology affects all word-formation processes in Greek, that is, compounding and derivation, as well as inflection. Given the fact that most borrowed items are molded as stems to fit in the Greek morphological system, they adjust either to a type of stem-based derived material bearing an overt derivational suffix (see verbs in Grekanico $(1,5)$, Pontic $(3,7)$ and Aivaliot $(4,8))$, or to non-derived stem-based inflected forms (see nouns and verbs in Heptanesian $(2,6)$ and verbs in Aivaliot (4)). Therefore, the requirement of Greek morphology to have stem-based inflected items, derived or non-derived, is fulfilled.

The question that needs an answer now is why Grekanico and Pontic speakers retain only the stems from Italo-Romance and Turkish adopted verbs, by

22 The vowel of the first syllable is changed into [e] because of the neighboring /i/, triggered by a Greek phonological law of vowel assimilation. This law is different from the vowel harmony observed in Turkish (see footnote ${ }^{18}$ ). 
subtracting inflection from the borrowed material and replacing it with the Greek suffixes (see (1) and (3)), whereas Heptanesian and Aivaliot ones reanalyze as stems full word-forms (see (2) and (4)). Turning back to socio-linguistic factors, I believe that this discrepancy could not be interpreted by appealing to linguistic properties alone. In accordance with Ralli (2016), I would like to propose that both the Grekanico and Pontic speakers who were subject to a long-term dominance by Italo-Romance and Turkish, respectively, and generally had a good command of those languages, have reacted against a simple and unelaborated borrowing of verbs by creating more hellenicized forms, those carrying Greek derivation (the $-e v$ - suffix) and inflection. ${ }^{23}$ Significant support to this process was also provided by their traditionally known conservatism towards innovation: Grekanico and Pontic are well known for preserving a considerable number of archaic (Ancient Greek or Medieval) features, as shown by Rohlfs (1933; 1977; 1997), Caratzas (1958) and Karanastasis (1997) for Grekanico, Manolessou and Pantelidis (2011) and Sitaridou (2014) for Pontic. These elements have led scholars to consider them as the two Modern Greek dialects closer to Ancient Greek. ${ }^{24}$ In fact, the verbalizer - $e v$-, the presence of which is attested in verbal loans, belongs to the Ancient Greek features: -ev-

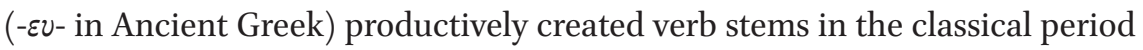
(fifth-fourth century ВСЕ), as asserted by Chantraine (1945: 244), and is still the most productively employed verbalizer in both Grekanico and Pontic. It is less frequent in Standard Modern Greek and the other Modern Greek dialects, compared to another verbalizer, $-i z$-, which has gained its vast productivity after the Hellenistic period (Browning, 2004: 92-93). On the basis of these considerations, I would like to conclude that the outcome of verb integration in Grekanico and Pontic has been shaped by the interplay of both intra-linguistic and extra-linguistic factors. On the one hand, the speakers' good command of the source language and their reaction to heavy borrowing facilitate but also constrain the type of transferred material. On the other hand, a decisive role is played by the morphological properties of the target language, since both Grekanico and Pontic retain only the stem from the borrowed words -stems being the base of all native verbs- and select the highly productive derivational suffix -ev-as integrating element.

23 Enrique-Arias (2010: 97) has reached a more or less similar conclusion for a contact situation involving Spanish and Catalan in Majorca.

24 For instance, the pronunciation of ' $\eta$ ' as [ $\varepsilon$ :] in Pontic (Manolessou and Pantelidis 2011) and the use of non-finite forms after the verb 'can' (Squillaci 2016) are among the preserved features. Interestingly, Manolessou (2005: 117) claims that the archaisms, shown in Grekanico on all grammatical levels, phonology and vocabulary, may be due to the fact that communication between South Italy and the rest of the Greek-speaking world was interrupted in the Middle Ages, before the thirteenth century CE. 
As shown in the following paragraphs, the close interaction of intra-linguistic and extra-linguistic factors is not limited to Grekanico and Pontic but applies to verb borrowing and integration in all dialects under consideration. For instance, the low command of Turkish and the socio-political conditions in the Aivali area can explain why Aivaliot speakers do not analyze the Turkish adopted verbs in order to keep the stem, but reanalyze as stems the entire word forms. At the beginning of the twentieth century, as reported in the literature (Sakkaris, 1920), Aivali was inhabited by an entirely Greek-speaking population, had a kind of socio-political autonomy, granted by the Ottoman authorities, and education was provided in Greek, while Turkish or French were taught at school as second language. Women did not usually speak Turkish and those men who knew Turkish used it in trade and administration. Therefore, living in a mainly Greek-speaking environment, Aivaliot speakers borrowed the entire verbal words from Turkish, without feeling the need, or being able to further analyze their structure. ${ }^{25}$ Moreover, they applied the indirect insertion strategy to accommodate the verbal loans with the use of -iz-, instead of that of -ev- observed in Pontic (3). I believe that a possible justification for the choice of the particular integrator can be found in the high frequency of $-i z$ - in this dialect, which surmounts that of $-e v-{ }^{26}$

However, an explanation is still pending as to why Aivaliot speakers resort to the adoption of the third person singular form of the Turkish past perfective tense. ${ }^{27}$ Along the lines of Ralli $(2012 b ; 2016 ; 2019 b)$ and Bağrıçık et al.

25 This socio-linguistic explanation could not apply to Cappadocian, where Turkish verbal loans are integrated exactly like the Aivaliot ones (Dawkins, 1916), in spite of the fact that Cappadocians had been under the heaviest contact with Turkish, from all Asia Minor Greek speaking populations, and had the highest command of the Turkish language. A different explanation is needed for Cappadocian verb accommodation which exceeds the limits of this article. Nevertheless, I would like to suggest that Cappadocian speakers do not analyze the Turkish past perfective forms in order to keep only the stem because, contrary to the other Greek speakers, they base word formation (among which loan verb integration) on entire words and not on stems (see Ralli, 2009 for an argumentation and examples on this position).

26 For details on the rise of productivity and the use of $-i z$ - in several dialects, see Chatzidakis (1905-1907) and Browning (2004), although there are no available statistics.

27 The use of a past perfective form seems to be a generalized process across the Balkan languages (see Breu, 1991a; 1991b). However, instead of attributing this feature to a mutual spread in the linguistic area of the Balkans that is, a feature of the so-called "Balkan Sprachbund", I propose that this follows from contact with the Greek language, where the use of the past perfective stem as base for word-formation purposes is already attested in the Hellenistic period (Chatzidakis, 1905-1907), that is, long before the creation of the Balkan Sprachbund. Therefore, I agree with Gardani, Loporcaro, and Giudici (2021) who claim that the processes underlying some basic developments of the Balkan languages do not belong to mutual convergence but to borrowing and reanalysis. 
(2015), I assume that among the most salient properties which can constrain lexical borrowing is a pre-existing similarity between the morphological features of the source and those of the target language. ${ }^{28}$ In this spirit, the choice of the most productively used -iz-in Aivaliot is also facilitated by the fact that there are Greek native verbal stems ending in $-i$ in the past perfective tense (aorist), something which renders them close to Turkish verbal forms in $-I$, as the examples in (9) illustrate. ${ }^{29}$ These verbs are distributed in two categories/ classes: the first inflection class/conjugation containing verbs with the verbalizer -i(z)- (e.g., cerð-iz-o 'to win' in Standard Modern Greek, cirð’zu in Aivaliot with mid-vowel raising, see footnote 17), and the second inflection class/conjugation (e.g., a a apó 'to love') consisting of verbs originating from the Ancient Greek 'contract' ones, ${ }^{30}$ any inflectional difference between the two classes being neutralized in the aorist paradigm.

(9) Past tense (aorist) of the Aivaliot native verbs cirðizu 'to gain, win' and arapó 'to love', and the Turkish verb sevmek 'to love'

\begin{tabular}{|c|c|c|c|}
\hline & a. Aivaliot & & b. Turkish \\
\hline 1SG & cérð(i)-sa $a^{31}$ & a qáp $(i)-s a$ & sevdi-m \\
\hline $2 S G$ & cérð(i)-sis & aráp $(i)$-sis & sevdi-n \\
\hline $3 \mathrm{SG}$ & cérð(i)-si & aráp $(i)-s i$ & sevdi \\
\hline 1PL & cirðí-sami & aүapí-sami & sevdi-k \\
\hline $2 \mathrm{PL}$ & cirðí-sati & arapí-sati & sevdi-niz \\
\hline 3PL & cirði-san & arapí-san & sevdi-ler \\
\hline
\end{tabular}

28 According to Meillet's (1921) "retentionist" position, in a language-contact situation, a transfer of morphological features is feasible if source and target languages share the same morphology (see also Gardani, 202ob and Gardani et al., 2015 for relevant discussion), a claim that has been reformulated as "morphological congruence" by Myers-Scotton (2002) and Field (2002). A weakened view of this position has been put forward by Jakobson (1938) who rejects the idea of "overall identity" and speaks about "morphological tendencies".

29 Note that /I/ in Turkish can change according to the vowel harmony law. For instance, burdI '(s)he twisted' becomes burdu, dayandI '(s)he endured' dayand, and sevdI '(s)he loved' sevdi. As already mentioned in footnote ${ }^{18}$, vowel harmony does not exist in Aivaliot and / $\mathrm{I} /$ is usually realized as [i].

30 Ancient contract verbs had a stem final vowel $/ \bar{a} /, \mid \varepsilon /$, or $/ 0 /$, which was fused with the initial vowel of the inflectional ending by the so-called "contraction" phonological law (e.g., a $а$ ap $\bar{a}+\bar{o}->$ a a apō 'I love'). In the Hellenistic period, this law had already disappeared from the phonological system of Greek.

31 In the singular number, the unstressed /e/ has become [i] and the stem final vowel /i/ is put in parenthesis because it is deleted also in unstressed position (see footnote ${ }^{17}$ ). /i/ appears in plural because the stress is shifted on it. Note also that the initial -s- of the ending is the marker of the past perfective and $-a,-i s,-i$, -ame, -ate, -an, the personal endings indicating the features of past, person and number. For clarity reasons, $-s$ - and the personal endings are taken together. For a detailed analysis of Greek inflection, see Ralli (2005). 
This form similarity has most probably led the Aivaliot speakers to adopt the Turkish past tense forms, reanalyze them as stems and further combine them with the Greek inflectional endings, as in (10).

(10) Adoption and integration of the Turkish verb form kazandı '(s)he earned'

$\begin{array}{ll} & \text { Aorist (past perfective tense) } \\ \text { ISG } & \text { kazád }(i) \text {-sa } \\ \text { 2SG } & \text { kazád }(i) \text {-sis } \\ \text { 3SG } & \text { kazád }(i) \text {-si } \\ \text { 1PL } & \text { kazadí-sami } \\ \text { 2PL } & \text { kazadí-sati } \\ \text { 3PL } & \text { kazadí-san }\end{array}$

Moreover, the selection of the third person could be triggered by the fact that, in the Turkish past tense paradigm, this was the only form with no overt inflectional ending (see $9 \mathrm{~b}$ ), and thus, the easiest form to be adopted, being the most unmarked one. Besides, as claimed in the literature, the third person singular is prone to become the base for morphological changes (Joseph, 1998: 368 ).

Once the formation of the past tense is achieved, the rest of the verbal paradigm, that is, the personal forms of the present tense, imperfect and future tense, is shaped, either with the help of the verbalizer - $i z$ - (analogically to the native Greek verbs in -iz- e.g., cerðizo 'to gain, win' in (9a)) or without it (following the native verbs of the second inflection class, e.g., arapó 'to love' in (9a)). Thus, the use of two alternative strategies, the direct and the indirect one, for the same loan can be justified, but the particular choice of the first or the second strategy, or even that of both strategies, seems to be at random. For an illustration, see the paradigms of the present tense in (11).

(11) Aivaliot present tense of the parallel integrated forms of the Turkish verb aktarmak 'to transfer' ('overthrow' in Aivaliot)

$\begin{array}{lll}\text { 1SG } & \text { axtardizu } & \text { axtardó } \\ 2 \mathrm{SG} & \text { axtardís }{ }^{32} & \text { axtardás } \\ \text { 3SG } & \text { axtardiz }(i) & \text { axtardá } \\ \text { 1PL } & \text { axtadízumi } & \text { axtardúmi } \\ \text { 2PL } & \text { axtardiziti } & \text { axtardúti } \\ \text { 3PL } & \text { axtardizin } & \text { axtardún }\end{array}$

32 The forms axtardijs and axtardiz phonologically derive from axtardizis and axtardizi after the deletion of unstressed final /i/. However, unstressed /i/ is kept in the plural number, probably for reasons due to the ease of pronunciation. 
Leaving aside Aivaliot, a point that needs to be clarified with respect to the Italo-Romance influence on Greek is why Heptanesian speakers adopt the entire Italo-Romance infinitival forms. Again, socio-linguistic reasons, together with the endogenous Greek morphological properties, could elucidate this behavior. Salvanos (1918) reports that, during the Venetian regime, Venetian and Italian were the dominant linguistic systems of the upper class in the Ionian islands, while people of the lower classes had small command of ItaloRomance and kept communicating in Greek. Crucial support to this observation is the statistic figures of 1849, provided by Soldatos (1967:100) for Corfu, the Ionian island with the heaviest Italo-Romance influence, where only 6,ooo speakers were bilingual, from a total of 200,00o inhabitants who spoke Greek, while only 100 people were reported to speak exclusively Italo-Romance. Compared to the Italo-Romance linguistic skills of Grekanico speakers, those of Heptanesian speakers were definitely lower. In accordance with what I have suggested for the Aivaliot speakers, this may explain why Heptanesians accept the entire word forms without resorting to their internal analysis, while the Grekanico speakers proceed to the analysis of borrowed words. In addition, while both Heptanesian and Grekanico had been under Italo-Romance influence, the socio-linguistic situation around Heptanesian was different from that of Grekanico, in that Heptanesian enjoyed a high prestige within the Greek-speaking world: it was used in literature and became one of the basic dialects for the development of Standard Modern Greek (Ralli, 2013). On the contrary, Grekanico was considered as a linguistic variety spoken by a lower class of peasants, in poor and isolated areas of South Italy (Katsoyannou, 1999). I believe that, as opposed to the Grekanico speakers who felt that their language was endangered and by reaction opted for a high hellenicization of verbal loans, Heptanesians did not probably sense the need to analyze the Italo-Romance words and imported infinitives as a whole.

A further point requiring elucidation is why Aivaliot speakers do not mold their verbal loans on the basis of an infinitival form, as Heptanesian speakers do with respect to Italo-Romance verbs. Assuming that Chatzidakis (19051907) is right, in the Hellenistic period, the aorist (past perfective) stem started being used as a base for the formation of verbal derivatives and this became a frequent tendency of Greek morphology across centuries. ${ }^{33}$ Since the integration of a verbal loan with the help of a derivational suffix (-iz-) could be considered as a kind of derivational process, this may explain why the form of Turkish verbs that is adopted and further reanalyzed as stem is that of the

33 Chatzidakis's proposal has been embraced by many linguists dealing with Greek. See, among others, Janse (2004). 
Turkish - $d I$ past tense. In the same spirit, even the Turkish verbal forms that are borrowed in Pontic (3) could be those in - $d I$ of the past perfective tense, and not the infinitival types in $-m A k$, because structurally, there is no formal difference between the Turkish stem in the infinitive and that in the past tense.

(12) Pontic

$\begin{array}{ll}\text { tokun-ev-o } & \text { 'to insult' } \\ \text { razan-ev-o } & \text { 'to earn' } \\ \text { axtar-ev-o } & \text { 'to overturn/transfer' } \\ \text { rurtar-ev-o } & \text { 'to free/save' } \\ \text { tajan-ev-o } & \text { 'to be patient' } \\ \text { pekle-ev-o } & \text { 'to wait' } \\ \text { šašir-ev-o } & \text { 'to be surprised' }\end{array}$

$\begin{array}{ll}\text { Turkish infinitive } & \begin{array}{l}\text { Turkish past } \\ \text { tense (3SG) }\end{array} \\ \text { dokun-mak } & \text { dokun-du } \\ \text { kazan-mak } & \text { kazan-dı } \\ \text { aktar-mak } & \text { aktar-dı } \\ \text { kurtar-mak } & \text { kurtar-dı } \\ \text { dayan-mak } & \text { dayan-dı } \\ \text { bekle-mek } & \text { bekle-di } \\ \text { şaşır-mak } & \text { şaşır-dı }\end{array}$

The problem, however, remains why Heptanesian speakers do not borrow a past perfective form of Italo-Romance verbs -like the Aivaliot speakers dobut select the infinitival forms. A solution could be found in the matching of features and structures between the source and the target language, that is, between Venetian and Heptanesian. According to Gambino (2007: cv) in old Venetian, the commonly employed form for the past perfective was the so-called "passato remoto". Its predominant use gave gradually place to the periphrastic passato prossimo, which became frequent only around the sixteenth century (Skubic, 1986: 31-43), and ultimately limited passato remoto in narrative contexts, around the nineteenth century (Loporcaro, 2013). Note now that the third person singular of the Venetian passato remoto, which could serve as the base for the integration of verbal loans in Heptanesian, was not uniform: its form varied depending on the verbal inflection class (Stussi, 1965: LXVIII), ending in - $a$ (e.g., cercà '(s)he searched'), -o (e.g., tochò '(s)he touched'), $-e$ (e.g., vendè '(s)he sold'), or $-i$ (e.g., mori '(s)he died'). I believe that this variance rendered difficult the matching of forms between the Heptanesian past perfective and the Venetian one. ${ }^{34}$ The absence of uniformity of the past perfective Venetian forms, as well as full access to infinitives that were productively used in Venetian probably led the Heptanesian speakers to adopt the most unmarked infinitival types. ${ }^{35}$

34 In the same spirit, even the periphrastic passato prossimo, built with the auxiliary avere 'to have' or essere 'to be' and the past participle of the main verb, could not be a suitable model for accommodating the Italo-Romance verbs. For an overview of simple and periphrastic past tenses in Romance languages, see Squartini and Bertinetto (2000).

35 It is worth mentioning that the borrowing of Italo-Romance infinitival forms in Greek had an impact on its morphology: it led to the innovative creation of a derivational suffix 
The last question needing an answer concerns the original verbal form transferred in Grekanico: is it the infinitive, like in Heptanesian, or the third person singular of the past tense as in Aivaliot (or even in Pontic)? Assuming that overt infinitives do not exist in Southern Italian, as mentioned in several works (see, among others, Rohlfs, 1977; 1997; ${ }^{36}$ Ledgeway, 1998; Squillaci, 2016), and according to the view that the one-word past perfective stems serve as the base for building derived structures in Greek (see above), one may suggest that, before resorting to an analysis in order to retain the stem, the Grekanico speakers adopt the past perfective forms, that is, the one-word forms of passato remoto, since the passato prossimo periphrastic ones have been recently inserted in the dialect, as suggested by Squillaci (2016: 62-74). See the following indicative examples taken from Greko (Squillaci, p.c.).

(13) Greko

$\begin{array}{lll}\text { nnat-eggu-o } & \text { 'to swim' } & \text { nnat-ari } \\ \text { spend-eggu-o } & \text { 'to spend' } & \text { spend-iri } \\ \text { piac-eggu-o } & \text { 'to like' } & \text { piac-iri } \\ \text { pens-eggu-o } & \text { 'to think' } & \text { pens-ari } \\ \text { arriv-eggu-o } & \text { 'to arrive' } & \text { rriv-ari } \\ \text { pass-eggu-o } & \text { 'to pass' } & \text { pass-ari } \\ \text { bbamp-eggu-o 'to go red' } & \text { bbamp-ari }\end{array}$

Calabrian (Infinitive) Calabrian (Passato remoto $3 \mathrm{SG}$ )

nnat-a-u

spend-i-u

piac-i-u

pens-a-u

rriv-a-u

pass- $a-u$

bbamp-a-u

Interestingly, contrary to Venetian verbs, which considerably vary in the third person singular of the past tense, depending on the verb, the corresponding forms in Calabrian display a certain uniformity: as shown in (13), they consist of a stem, a vowel $/ \mathrm{a} /$ or $/ \mathrm{i} /$ indicating the inflection class, and they all end in $-u$, the marker for the third person singular. ${ }^{37}$ This form regularity and the absence of infinitival forms may suggest that the adopted verbal material in Grekanico was initially drawn from the past perfective paradigm, before being submitted to an analysis in the purpose of supplying only the stem.

-ar-, based on the infinitival Italo-Romance marker -ar(e). - ar- is exclusively used for the formation of verbs of foreign origin, not necessarily Italo-Romance (e.g., Standard Modern Greek makijaro < French maquiller, Standard Modern Greek filmaro < English to film, etc.). It has been shaped by what Gardani (2016) calls "allogenous exaptation", since a change in function has occurred, from an inflectional marker of the source language to a derivational suffix in the target. See Ralli (2012a; 2016) for details.

36 Rohlfs (1977: §699) “[...] nelle parti più meridionali d'Italia, per influsso greco, l'uso dell'infinito è sconosciuto [...]" ['due to Greek influence, in the southernmost parts of Italy, the use of infinitive is unknown', translation by A.R.].

However, the endings may change depending on the Calabrian variety (Squillaci, p.c.). 
As shown in Section 3, extra-linguistic factors interact with the linguistic ones for the adoption and integration of verbs from Romance and Turkish in four Modern Greek dialects, two of them being influenced by Italo-Romance and the other two by Turkish. The investigated data confirm that the overall typology of the source language, semi-fusional or agglutinative, does not exert any specific influence on the accommodation of loans in the target language, and that the same type of loans can be found in varieties which are affected either by Italo-Romance or by Turkish. Nevertheless, the morphological properties of the two systems in contact, and a certain pre-existing similarity in the sub-domain of verbal forms were suggested to play a substantial role on how these forms are integrated in the target system.

I now examine a dialect which has undergone the influence of both Romance and Turkish, that is, Cypriot. The point at issue is to see not only whether Cypriot has borrowed verbs from these languages but how it has accommodated them and whether verb borrowing in Cypriot shows similarities with verb borrowing in the four dialects examined so far.

Cypriot is the Greek-based dialect of circa 700,00o Greek-Cypriot people in Cyprus and of Cypriots living abroad, many of them in Great Britain. It is also the dialect of many aged Turkish Cypriot people who are nowadays confined in the northern part of Cyprus. It is basically a spoken dialect, but it can be found in many literary and non-literary texts.

In its long history, Cyprus has been ruled by different people and has been subject to different civilizations. As a result, Cypriot has entered in contact with languages that left their marks on it, mostly on its lexicon. As early as in $63^{2}$ $\mathrm{CE}$, Byzantine Cyprus was invaded by the Arabs and was reconquered by the Byzantines only in 964. From 1191 to 1489, the island was governed by the French dynasty of Lusignan, who spoke a form of Old Provençal (Chatziioannou, 1936). In 1489, the Lusignans transferred Cyprus to the Republic of Venice, whose rule ended in 1571, when the island was captured by the Ottoman Turks. In 1878, Great Britain took over the administration, and finally, in 1960, Cyprus became independent. After the Turkish invasion in 1974, the actual Cypriot state has been limited to the southern part of the island, where Cypriot is currently used in everyday communication.

The first dialectal sources appear around the 14th century. They consist of a translation of the French legal text of Assizes, which was followed by two dialectal texts in the fifteenth century, the Chronicles of Leontios Machairas and Georgios Voustronios. ${ }^{38}$ Today, there are many lexical loans in the dialect,

38 See Beaudoin (1884) and Davy and Panayotou (2000) for details on these texts. 
among which French, mainly of Old Provençal origin, Italo-Romance, Turkish, Arab and English (Papapavlou, 1994). Therefore, Cypriot constitutes an excellent case for testing hypotheses about language contact involving one target and several source languages of different origin and typology. In what follows, I will focus on the Romance and Turkish verbal loans, the topic of this article.

(14) Cypriot (from Chatziioannou, 1936) Old Provençal (from Anglade, 1921)

\begin{tabular}{|c|c|c|}
\hline avanziazo & 'to move forward' & avançar \\
\hline anunsiazo & 'to announce' & anounçar \\
\hline ateniazo & 'to stick' & atenir \\
\hline finiazo & 'to end' & finir \\
\hline kufertiazo & 'to confort' & counfourtar \\
\hline kunsentiazo & 'to consent' & counsentir \\
\hline manteniazo & 'to maintain' & mantenir \\
\hline prezentiazo & 'to present' & presentar \\
\hline sufriazo & 'to suffer' & soufrir \\
\hline spiazo & 'to spy' & espiar \\
\hline
\end{tabular}

(15) Cypriot (from Chatziioannou, 1936) Venetian (from Boerio 1856)

$\begin{array}{lll}\text { vantzaro } & \text { 'to advance' } & \text { vanzar } \\ \text { vortaro } & \text { 'to call on' } & \text { voltar } \\ \text { kreparo } & \text { 'to crack' } & \text { crepar } \\ \text { pararo } & \text { 'to pay' } & \text { pagar } \\ \text { rifudaro } & \text { 'to refuse' } & \text { refudar } \\ \text { salvaro } & \text { 'to save' } & \text { salvar } \\ \text { saltaro } & \text { 'to jump' } & \text { saltar } \\ \text { stimaro } & \text { 'to estimate' } & \text { stimar } \\ \text { tratteniro } & \text { 'to hold back' } & \text { trategnir } \\ \text { fermaro } & \text { 'to stop' } & \text { fermar }\end{array}$

(16) Cypriot (from Chatzipieris and Kap- Turkish infinitive (3sg) atas, 2015)

\begin{tabular}{|c|c|c|}
\hline kaurtizo & 'to fry/sizzle' & kavurmak (kavurdu) \\
\hline kunuštizo & 'to kid around' & konušmak (konuštu) \\
\hline kazandízo & 'to win (a game)' & kazanmak (kazandı) \\
\hline $\begin{array}{l}\text { parlatízo/ } \\
\text { parlató }\end{array}$ & 'to tie' & bağlamak (bağladı) \\
\hline $\begin{array}{l}\text { peendizo/ } \\
\text { peendó }\end{array}$ & 'to respect' & beğenmek (beğendi) \\
\hline taništízo & 'to take advice' & današmak (današtı) \\
\hline sajdízo/sajdó & 'to appreciate' & saymak (saydı) \\
\hline čattizo/čattó & 'to match' & çatmak (çatı) \\
\hline
\end{tabular}




$\begin{array}{lll}\begin{array}{l}\text { dajandizo/ } \\ \text { dajandó }\end{array} & \text { 'to endure' } & \text { dayanmak (dayandı) } \\ \text { šastízo } & \text { 'to get confused' } & \text { šašmak (šaštı) }\end{array}$

The adoption of Romance and Turkish verbal loans in Cypriot is particularly intriguing, since it combines all strategies and patterns seen so far for Grekanico, Heptanesian, Pontic and Aivaliot. First, similarly to Grekanico (1) and Pontic (3), Cypriot has retained only the stem from the Old Provençal verbs and has accommodated it via the indirect strategy, that is with the help of an integrating element, the suffix -iaz-. The only difference between Cypriot and these two dialects is that whilst Grekanico and Pontic employ the -ev-suffix, Cypriot uses -iaz-. According to Chatzidakis (1905: 305), verbal derivation in -iaz- was particularly productive in Medieval Cyprus, contrary to the other parts of the Greek speaking world, where -iz- (see Aivaliot in (4)) or -ev- (see Grekanico and Pontic in (1) and (3)) were most frequent. I have already proposed that high productivity constitutes a decisive factor for the selection of an integrating element. Thus, it is not surprising that, during the Lusignan rule (from 1191 to 1489), Cypriot has accommodated Old Provençal verbs by using the most productive -iaz-. A crucial question that arises though is whether, before getting analyzed, the Old Provençal verbs had entered Cypriot as infinitival or as past tense forms. Along the lines of what I have suggested for Heptanesian, I am tempted to propose that Cypriots had adopted the infinitival forms, as being the most unmarked and regular ones, because the third person singular of the past perfective (simple past) paradigm was not uniform for all verbs. Following Anglade (1921), Old Provençal verbs in -ar (e.g., avançar 'to move forward') form their third person singular of the past perfective tense in -et (pronounced as [e]), e.g., avancet, whereas a suffix -gu- appears in the paradigms of verbs in -ir, -er and -re (except for those in -dre, e.g., vendre 'to sell'). See, for instance, the form finiguet of the verb finir 'to end'.

Second, like Heptanesians (2) and Aivaliots (4), Cypriots borrow from Venetian the entire infinitival forms and from Turkish the third person singular of the past tense. In the first case, only the direct insertion is used, similarly to Heptanesian, while in the second case, both strategies alternate for most verbs, the indirect one -with - $i z$ - as integrating element- and the direct strategy. As seen in Section 3.4, this alternation also occurs in the accommodation of Turkish loans in Aivaliot. Again, I would like to propose that this peculiar situation is due to the interplay of linguistic and sociolinguistic factors. According to Dendias (1923: 157), during the French regime in Cyprus, the degree of 
education was relatively high, and French and Greek were taught at schools. As a consequence, when borrowing occurred, loan verbs were heavily hellenicized by the Cypriot speakers, who could analyze them, retain the stems and combine them with the Greek integrating suffix -iaz- before adding the Greek inflectional ending. In contrast, during the Venetian and the Ottoman periods, schools were closed, education was poor and the command of the politically dominant language was definitely low. I, thus, assume that educational deficiency and low command of the source language led the speakers borrow the entire Venetian infinitives or the Turkish past forms, reanalyze them as stems and add the inflectional endings without proceeding to a word internal analysis. That the socio-linguistic context is critical for the adoption of a specific strategy in loan verb accommodation gets further support by the fact that, even during the Lusignan rule and because of a flourishing trade with Venice, Venetian verbs had entered the Cypriot vocabulary as verbs in -iaz-o and not as verbs in -ar-o. The example sizur-iaz-o 'to make sure', adopted from the Venetian sicurar according to Chatzidakis (1905: 304), adds substantial proof to this suggestion. However, the Old Provençal counterpart asegurar makes its origin disputable. ${ }^{39}$

To partially sum up, the Cypriot case shows that borrowing in a particular linguistic system can be constrained by the interplay of linguistic and extra-linguistic factors. That is, high linguistic skills or educational deficiency can lead to heavy or weak integration of the borrowed material, the form of which is determined by the morphological properties of the target language, while a certain matching of forms between the two languages in contact may also be at play. The situation where linguistic factors interact with extra-linguistic ones for molding the accommodation of loan items is not unknown in other contact settings. See, for instance, Clements and Luís (2015) on how borrowing is affected in Korlai Indo-Portuguese.

This article compares Romance and Turkish verbal loans in five Modern Greek dialects, Grekanico, Heptanesian, Pontic, Aivaliot and Cypriot, revealing that there is no consistency in the way loans are adopted and accommodated. The absence of uniformity is observed not only from dialect to dialect, and from source language to source language, but even within the same target system. It is shown that the various integration strategies and patterns are not

39 On the difficulty of determining the origin of borrowed words, see Minervini (2019). 
distributed according to the particular source or target languages, since the same strategy or pattern can be found in dialects which are in contact with different languages and different strategies or patterns can alternate within the same dialect influenced by the same source language. While borrowing of verbs occurs in a heavy-contact situation, the native morphological properties, principally those of the target language, as well as a certain compatibility between the transferred forms of the source language and the corresponding native forms of the target have been proposed to be the determining linguistic factors for verbal loan integration, together with the extra-linguistic factors referring to the intensity of contact, a profound knowledge of the source language, the degree of education and the speakers' sociolinguistic attitude towards the dominant language. As far as the native morphological characteristics are concerned, those which seem to play a predominant role in the integration of verbal loans is the stem-based property of Greek to build its derived and inflected formations on stems, and the prevalence of the past perfective stem as a base for the creation of derivative structures. It is also demonstrated that a more elaborated accommodation of the transferred verbs results in the adoption of an integrating element, the choice of which is controlled by productivity considerations. Agreeing with Wohlgemuth (2009), this work proves that verbs can be borrowed as such, provided that certain conditions are met, contra Moravcsik (1978:111), who has suggested that a lexical item whose meaning is verbal cannot be included in the set of borrowed elements without being nominalized.

Finally, this study shows that verb borrowing from Turkish does not seem to belong to the Balkan Sprachbund features, at least as far as Greek is concerned. First, there are Greek varieties which are outside the geographic boundaries of the Balkans, that is, Pontic, Grekanico and Cypriot (even Cappadocian, mentioned in footnotes 18 and 25) but share the same type of loan integration as other dialects which belong to the Balkan area, that is, Heptanesian and Aivaliot. Second, languages which are traditionally considered to belong to the Balkan Sprachbund, as for instance, Bulgarian, do not integrate their Turkish verbal loans directly from Turkish, as is the Greek case, but through the mediation of Greek: Bulgarian adopts the past perfective stems of Turkish loans as they appear in Greek, that is, with the Greek perfective marker-s- (see footnote ${ }^{31}$ ), adds the Bulgarian verbalizer - $v a$ - and the Bulgarian personal ending (e.g., Bulgarian bastisvam 'I attack suddenly/stomp/print' < Turkish past perfective $b a s t \iota+$ Greek perfective marker $-s-+$ Bulgarian verbalizer $-v a-+$ Bulgarian 1sg $-m$ ). Thus, along the lines of Gardani, Loporcaro, and Giudici (2021) I believe that change in the Balkan languages does not necessarily converge but is due to a pairwise contact over a long period of time. 


\section{Acknowledgments}

I am much indebted to Michele Loporcaro, Maria Olimpia Squillaci, Bernat Giély and Milena Milenova for their valuable assistance with Venetian, Greko, Old Provençal and Bulgarian. I am grateful to Francesco Gardani and the two anonymous reviewers whose comments and suggestions made this work benefit greatly. Special thanks are also due to Stavros Bompolas for helping me formatting the article.

\section{References}

Anglade, Joseph. 1921. Grammaire de l'ancien provençal ou ancienne langue d'oc. Paris: Klincksieck.

Bağnaçık, Metin, Angela Ralli, and Dimitra Melissaropoulou. 2015. Borrowing verbs from Oghuz Turkic: two linguistic areas. In Francesco Gardani, Peter Arkadiev and Nino Amiridze (eds.), Borrowed Morphology, 109-136. Berlin: De Gruyter Mouton.

Beaudoin, Mondry. 1884. Étude du dialecte chypriote moderne et médiéval. Paris: Ernest Thorin.

Berikashvili, Svetlana. 2017. Morphological Aspects of Pontic Greek Spoken in Georgia. Munich: LINCOM.

Boerio, Giuseppe. 1856. Dizionario del dialetto veneziano. 2nd edn. Venice: Premiata tipografia di Giovanni Cecchini.

Breu, Walter. 1991a. Abweichungen vom phonetischen Prinzip bei der Integration von Lehnwörtern. In Klaus Hartenstein and Helmut Jachnow (eds.), Slavistische Linguistik 199o: Referate des XVI. Konstanzer Slavistischen Arbeitstreffens Bochum/ Löllinghausen 19.-21.9.1990 (Slavistische Beiträge 274), 36-69. Munich: Otto Sagner.

Breu, Walter. 1991b. System und Analogie bei der Integration von Lehnwörtern: Versuch einer Klassifikation. Incontri Linguistici 14(1): 13-28.

Browning, Robert. 2004. Elliniki Glossa, Meseoniki ke Nea [Greek Language, Medieval and Modern]. Athens: Papadimas. [Originally published as Medieval and Modern Greek. London: Hutchinson University Library 1969].

Bryer, Anthony. 1975. Greeks and Türkmens: The Pontic exception. Dumbarton Oaks Papers 29: 113-148.

Caracausi, Girolamo. 1979. Testi neogreci di Calabria. Indice lessicale. Palermo: Istituto Siciliano di Studi Bizantini e Neoellenici.

Caratzas, Stamatis. 1958. L’origine des dialectes néo-grecs de l'Italie méridionale. In Collection de l'Institut d'Études Byzantines et Néo-helléniques 18. Paris: Les Belles Lettres. 


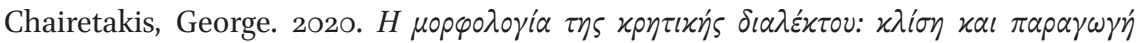
[The morphology of the Cretan dialect: inflection and derivation]. PhD dissertation, University of Patras.

Chantraine, Pierre. 1945. Morphologie historique du grec. Paris: Klincksieck.

Chatzidakis, Georgios. 1905. Meseonika ke Nea Ellinika [Medieval and Modern Greek], vol. 1. Athens: Sakellarios.

Chatziioannou, Kyriakos. 1936. Peri ton en ti Meseoniki ke Neotera Kypriaki Ksenon Glossikon Stichion [About the Foreign Linguistic Elements in Medieval and Modern Cypriot]. Athens: Xenou.

Chatzipieris, Iakovos and Orhan Kapatas. 2015. Koino Leksiko tis Ellinokyrpiakis ke Tourkokypriakis Dialektou [Common Dictionary of the Greek-Cypriot and TurkishCypriot Dialect]. Nicosia: Lithographica Ltd.

Clements, Clancy, J. and Ana R. Luís. 2015. Contact intensity and the borrowing of bound morphology in Korlai Indo-Portuguese. In Francesco Gardani, Peter Arkadiev and Nino Amiridze (eds.), Borrowed Morphology, 219-240. Berlin: De Gruyter Mouton.

Contosopoulos, Nicolaos 2001. Dialects and Idioms of Modern Greek. Athens: Grigoris.

Cortelazzo, Manlio. 2017. Dizionario veneziano della lingua e della cultura popolare nel XVI secolo. Limena, Padova: La Linea.

Davy, John and Anna Panayotou. 200o. French loans in Cypriot Greek. In Jean Pouilloux (ed.), Travaux de la Maison de l'Orient Méditerranéen, 113-125. Lyon: Maison de l'Orient et de la Méditerranée.

Dawkins, Richard. 1916. Modern Greek in Asia Minor. Cambridge: Cambridge University Press.

Deffner, Michael. 1881. Zakonische Grammatik. Berlin: Weidmannsche Buchhandlung.

Dendias, Michael. 1923. Peri ton en ti Kypriaki rimaton ek tis Italikis ke tis Gallikis [About the Italian and French verbs in Cypriot]. Glossika Simeiomata, 142-165.

Drettas, Georges. 1997. Aspects pontiques. Paris: Arp.

Enrique-Arias, Andrés. 2010. On language contact as an inhibitor of language change: The Spanish of Catalan bilinguals in Majorca. In Anne Breitbarth, Christopher Lucas, Sheila Wattsy, and David Willis (eds.), Continuity and Change in Grammar, 97-118. Amsterdam: Benjamins.

Fanciullo, Franco. 2001. On the origins of Greek in Southern Italy. In Angela Ralli, Brian Joseph and Mark Janse (eds.), Proceedings of the ist International Conference of Modern Greek Dialects and Linguistic Theory, 67-78. Patras: University of Patras.

Fanciullo, Franco. 2008. Gli italianismi del neogreco. L'Italia Dialettale 69: 1-41.

Field, Fredric. 2002. Linguistic Borrowing in Bilingual Contexts. Amsterdam: Benjamins.

Gambino, Francesca (ed.). 2007. Ivangeli in antico veneziano, manoscritto Marciano it. I, 3 (4889). Rome: Antenore.

Gardani, Francesco. 2016. Allogenous exaptation. In Muriel Norde and Freek van de Velde (eds.), Exaptation and Language Change, 227-261. Amsterdam: Benjamins. 
Gardani, Francesco. 2020a. Borrowing matter and pattern in morphology. An overview. Morphology 3o(4): 263-282.

Gardani, Francesco. 202ob. Morphology and contact-induced language change. In Anthony Grant (ed.), The Oxford Handbook of Language Contact, 96-122. Oxford: Oxford University Press.

Gardani, Francesco, Peter Arkadiev, and Nino Amiridze. 2015. Borrowed morphology: An overview. In Francesco Gardani, Peter Arkadiev and Nino Amiridze (eds.), Borrowed Morphology, 1-26. Berlin: De Gruyter Mouton.

Gardani, Francesco, Michele Loporcaro, and Alberto Giudici. 2021. In and around the Balkans: Romance languages and the making of multi-layered languages. Journal of Language Contact 14(1):1-23.

Haspelmath, Martin. 20o9. Lexical borrowing: Concepts and issues. In Martin Haspelmath and Uri Tadmor (eds.), Loanwords in the World's Languages: A Comparative Handbook, 35-54. Berlin: Mouton De Gruyter.

Henrich, Günther Steffen. 199o. The Pontic elements in a Greek-language islamic text of the 1500 . In Festschrift in memoriam of Stamatis Caratzas, 355-374. Thessaloniki: Aristotle University of Thessaloniki.

Henrich, Günther Steffen. 2011. First appearance of grammatical innovations of the Pontic and Crimean Pontic dialect. Neoelliniki Dialektologia 6: 89-1og.

Hitiris, Georgios. 1987. Kerkyraiko Glossario [Corfiot Glossary]. Corfu.

Hock, Hans Henrich and Brian Joseph. 1996. Language History, Language Change and Language Relationship. Berlin: Mouton De Gruyter.

Horrocks, Geoffrey. 1997. Greek: A History of the Language and its Speakers. London: Longman.

Jakobson, Roman. 1938. Sur la théorie des affinités phonologiques entre les langues. In Actes du 4e Congrès International des Linguistes, 48-59. Copenhagen: Einar Munskgaard.

Janse, Mark. 2004. Animacy, definiteness, and case in Cappadocian and other Asia Minor dialects. Journal of Greek Linguistics 5: 3-26.

Joseph, Brian. 1998. Diachronic morphology. In Arnold Zwicky and Andrew Spencer (eds.), The Handbook of Morphology, 351-373. Oxford: Blackwell.

Kahane, Henry and Renée Kahane. 1982. The Western impact on Byzantium: The linguistic evidence. Dumbarton Oaks Papers 36: 127-153.

Karanastasis, Anastasios. 1984. Istorikon Leksikon ton Ellinikon Idiomaton tis Kato Italias [Historical Dictionary of the Greek Dialects of South Italy]. Athens: Academy of Athens.

Karanastasis, Anastasios. 1997. Grammatiki ton Ellinikon Idiomaton tis Kato Italias [Grammar of the Greek Dialects of South Italy]. Athens: Academy of Athens.

Katsoyannou, Marianna. 1995. Le parler greco de Galliciano (Italia): description d'une langue en voie de disparition. $\mathrm{PhD}$ dissertation, Université de Paris VII. 
Katsoyannou, Marianna. 1999. To idioma tis Calavrias [The dialect of Calabria]. In Tasos Christidis (ed.), Dialectal Enclaves of the Greek Language, 39-45. Thessaloniki: Center of the Greek Language.

Katsouda, Georgia. 2016. To Idioma ton Kythiron: Perigrafi ke Analysi [The Dialect of Cythera: Description and Analysis]. Athens: Cythera Association.

Kitromilides, Paschalis and Alexis Alexandris. 1984. Ethnic survival, nationalism and forced migration. The historical demography of the Greek community of Asia Minor at the close of the Ottoman era. Deltio Kentrou Mikrasiatikon Spoudon 5: 9-44.

Konomos, Dinos. 2003. Leksiko tis Zakynthou [Dictionary of Zante]. 2nd edn. Zante: Trimorfo.

Korosidou-Karra, Ermioni. 2003. Ta Romanika (Italika - Gallica) Dania sto Sinxrono Idioma tis Zakynthou [The Romance Borrowings in the Zante dialect]. PhD dissertation, Aristotle University of Thessaloniki.

Krimpas, Panagiotis. 2018. Italian. In George Kanarakis (ed.), The Legacy of the Greek Language, 37-73. New York: Peridot.

Ledgeway, Adam. 1998. Variation in the Romance infinitive: The case of Southern Calabrian inflected infinitive. Transactions of the Philological Society 96:1-61.

Ledgeway, Adam, Norma Schifano and Giuseppina Silvestri. 2021. The negative imperative in southern Calabria. Spirito greco, materia romanza again? Journal of Language Contact 14(1): 184-219.

Loporcaro, Michele. 2013. Profilo linguistico dei dialetti italiani. 2nd edn. Rome-Bari: Laterza.

Mackridge, Peter. 1987. Greek speaking Moslems of North-East Turkey: Prolegomena to a study of the Ophitic sub-dialect of Pontic. Byzantine and Modern Greek Studies 11: $115^{-137 .}$

Makri, Vasiliki. 2020. The Formal Expression of Grammatical Gender in a Modern Greek Dialect Affected by Italo-Romance. PhD dissertation, University of Patras.

Manolessou, Io. 2005. The Greek dialects of Southern Italy: An overview. KAMPOS 13: 103-125.

Manolessou, Io. 2019. The historical background of the Asia Minor dialects. In Angela Ralli (ed.), The Morphology of Asia Minor Dialects, 20-65. Leiden: Brill.

Manolessou, Io and Nikolaos Pantelidis. 2011. To archaeo elliniko / $\varepsilon$ :/ stin Pontiaki [Ancient Greek /ع:/ in Pontic]. Neoelliniki Dialektologia 6: 245-271.

Manolessou, Io and Angela Ralli. 2020. On borrowing and integrating Italo-Romance nouns in South Italian Greek. In Patrizia del Puente, Francesca Guazzelli, Lucia Molinu, and Simone Pisano (eds.), Festschrift to Franco Fanciullo, 417-434. Alessandria: Edizioni dell'Orso.

Martino, Paolo. 1979. L'isola grecanica dell'Aspromonte; aspetti sociolinguistici. In Federico Albano Leoni (ed.), I dialetti e le lingue delle minoranze difronte all'italiano: Atti del XI Congresso Internazionale di Studi, Cagliari, 27-30 Maggio 1977, 305-341. Rome: Bulzoni. 
Matras, Yaron. 2009. Language Contact. Cambridge: Cambridge University Press.

Meillet, Antoine. 1921. Linguistique historique et linguistique générale. Paris: Champion.

Minervini, Laura. 2019. Veneziano e francese nell'Oriente latino. In Daniele Baglioni (ed.), Il veneziano «de là da mar». Contesti, testi, dinamiche del contatto linguistico e culturale, 177-200. Berlin: De Gruyter.

Moravcsik, Edith A. 1978. Language contact. In Joseph H. Greenberg, Charles A. Ferguson, and Edith A. Moravcsik (eds.), Universals of Human Language: Method \& Theory, 93-122. Stanford: Stanford University Press.

Morosi, Giuseppe. 1870. Studio sui dialetti greci della Terra di Otranto. Lecce: Tipografia Editrice Salentina.

Myers-Scotton, Carol. 2002. Contact Linguistics: Bilingual Encounters and Grammatical Outcomes. Oxford: Oxford University Press.

Newton, Brian. 1972. Cypriot Greek: Its Phonology and Inflections. The Hague: Mouton.

Oikonomidis, Dimosthenis. 1958. Grammatiki tis Ellinikis Dialektou tou Pontou [Grammar of Pontic Greek]. Athens: Academy of Athens.

Özkan, Hakan. 2013. The Pontic Greek spoken by Muslims in the villages of Beşköy in the province of present-day Trabzon. Byzantine and Modern Greek Studies 37(1): 130-15o.

Papadopoulos, Anthimos. 1955. Istoriki Grammatiki tis Pontikis Dialektou [Historical Grammar of the Pontic Dialect]. Athens: Epitropi Pontiakon Meleton.

Papadopoulos, Anthimos. 1958-1961. Istorikon Leksikon tis Pontikis Dialektou [Historical Dictionary of the Pontic Dialect]. Athens: Epitropi Pontiakon Meleton.

Papapavlou, Andreas. 1994. Language Contact and Lexical Borrowing in the Greek Cypriot Dialect. Athens: Grivas.

Parlangeli, Oronzo. 1953. Sui dialetti romanzi e romaici del Salento. Memorie dell'Instituto Lombardo di Scienze e Lettere (Classe di Lettere) 25: 93-198.

Profili, Olga. 1983. Le parler grico de Corigliano d'Otranto (provence Lecce, Italie): Phénomènes d'interférence entre le parler grec et les parlers romans environnants, ainsi qu'avec l'italien. $\mathrm{PhD}$ dissertation, Université Stendhal, Grenoble.

Ralli, Angela. 2005. Morfologia [Morphology]. Athens: Patakis. Updated and enriched version published in 2021.

Ralli, Angela. 2009. Morphology meets dialectology: Insights from Modern Greek dialects. Morphology 19(1): 87-105.

Ralli, Angela. 2012a. Verbal loanblends in Griko and Heptanesian: A case study of contact morphology. L'Italia Dialettale LXXIII: 111-132.

Ralli, Angela. 2012b. Morphology in language contact: Verbal loanblend formation in Asia Minor Greek (Aivaliot). In Martine Vanhove, Thomas Stolz, Aina Urdze, and Hitomi Otsuka (eds.), Morphologies in Contact, 185-201. Berlin: Akademie Verlag.

Ralli, Angela. 2013. Greek. Revue belge de philologie et d'histoire 9o: 939-966. 
Ralli, Angela. 2015. Greek. In Peter Müller, Ingeborg Ohnheiser, Susan Olsen, and Franz Rainer (eds.), Word Formation. An International Handbook of the Languages of Europe, 3138-3156. Berlin: Mouton De Gruyter.

Ralli, Angela. 2016. Strategies and patterns of loan verb integration in Modern Greek varieties. In Angela Ralli (ed.), Contact Morphology in Modern Greek Dialects, 73-108. Newcastle upon Tyne: Cambridge Scholars Publishing.

Ralli, Angela. 2017. Dictionary of the Dialectal Varieties of Moschonisia, Aivali and Eastern Lesbos. Athens: Foundation of Historical Studies.

Ralli, Angela. 2019a. Greek in contact with Romance. In Michele Loporcaro and Francesco Gardani (eds.), The Oxford Encyclopedia of Romance Linguistics. New York: Oxford University Press. DOI: 10.1093/acrefore/9780199384655.013.422.

Ralli, Angela. 2019b. Affixoids and verb borrowing in Aivaliot morphology. In Angela Ralli (ed.), The Morphology of Asia Minor Greek. Selected Topics, 221-254. Leiden: Brill.

Ralli, Angela, Marianna Gkiouleka, and Vasiliki Makri. 2015. Gender and inflection class in loan-noun integration. SKASE Journal of Theoretical Linguistics 12(3): 422-46o.

Ralli, Angela and Vasiliki Makri. 2020. Examining the integration of borrowed nouns in immigrant speech: The case of Canadian-Greek. In Pius ten Hacken and Renáta Panocová (eds.), The Interaction of Borrowing and Word Formation, 237-258. Edinburgh: Edinburgh University Press.

Rohlfs, Gerhard. 1933. Scavi Linguistici nella Magna Grecia. Rome: Collezione Meridionale.

Rohlfs, Gerhard. 1977. Grammatica storica dei dialetti italogreci (Calabria, Salento). Munich: Beck.

Rohlfs, Gerhard. 1997. Studi e ricerche su lingue e dialetti d'Italia. 2nd edn. Milan: Sansoni. [1st edn. Florence 1972].

Sakel, Jeanette. 2007. Types of loan: Matter and pattern. In Yaron Matras and Jeanette Sakel (eds.), Grammatical Borrowing in Cross-Linguistic Perspective, 15-29. Berlin: Mouton de Gruyter.

Sakkaris, Georgios. 1920. History of Kydonies. Kydonies. [Reprinted in 1940 in Athens, by the Academy of Athens].

Sakkaris, Georgios. 1940. On the Kydonies dialect in comparison with Lesbian. Mikrasiatika Chronika 3: 74-141.

Sakkaris, Georgios. 1948. On the Kydonies dialect. Vocabulary. Mikrasiatika Chronika 4: 49-81.

Salvanos, Georgios. 1918. Meleti peri tou Glossikou Idiomatos ton en Kerkyra Argyradon [Study of the Dialect of Corfiot Argyrades]. Athens.

Seifart, Frank, Jan Strunk, Swintha Danielsen, Iren Hartmann, Brigitte Pakendorf, Søren Wichmann, Alena Witzlack-Makarevich, Nivja H. de Jong, and Balthasar Bickel. 
2018. Nouns slow down speech across structurally and culturally diverse languages. Proceedings of the National Academy of Sciences 115(22): 5720-5725.

Simiris, Dimitris. 2017. To Glossiko Idioma tis Ithakis [The Dialect of Ithaca]. Patras: Laboratory of Modern Greek Dialects and Community of Ithaca.

Sitaridou, Ioanna. 2013. Greek-speaking enclaves in Pontus today: The documentation and revitalization of Romeyka. In Mari C. Jones and Sarah Ogilvie (eds.), Keeping Languages Alive: Language Endangerment, Documentation, Pedagogy and Revitalization, 98-112. Cambridge: Cambridge University Press.

Sitaridou, Ioanna. 2014. The Romeyka infinitive: Continuity, contact and change in the Hellenic varieties of Pontus. Diachronica 31(1): 23-73.

Skubic, Mitja. 1986. Passato prossimo e passato remoto nei dialetti veneti. In Manlio Cortelazzo (ed.), Guida ai dialetti veneti V, 31-43. Padua: Cleup.

Soldatos, Konstantinos. 1967. I elliniki glossa sta Eptanisa [The Greek language in the Heptanesian islands]. Kerkyraika Chronika 13-14: 84-104.

Squartini, Mario and Pier Marco Bertinetto. 200o. The simple and compound past in Romance languages. In Östen Dahl (ed.), Tense and Aspect in the Languages of Europe, 403-439. Berlin: Mouton De Gruyter.

Squillaci, Maria Olimpia. 2016. When Greek Meets Romance: A Morphosyntactic Investigation of Language Contact in Aspromonte. $\mathrm{PhD}$ dissertation, Cambridge University.

Stussi, Alfredo (ed.). 1965. Testi veneziani del Duecento e dei primi del Trecento. Pisa: Nistri-Lischi.

Telmon, Tullio. 1992. Le minoranze linguistiche in Italia. Turin: Edizioni dell'Orso.

Thomason, Sarah. 2001. Language Contact. An Introduction. Edinburgh: Edinburgh University Press.

Trudgill, Peter. 2003. Modern Greek dialects: A preliminary classification. Journal of Greek Linguistics 4: 45-63.

Vryonis, Speros. 1971. The Decline of Medieval Hellenism in Asia Minor and the Process of Islamization from the Eleventh through the Fifteenth Century. Berkeley: University of California Press.

Wichmann, Søren and Jan Wohlgemuth. 2008. Loan verbs in a typological perspective. In Thomas Stolz, Dick Bakker and Rosa Salas Palomo (eds.), Aspects of Language Contact. New Theoretical, Methodological and Empirical Findings with Special Focus on Romancisation Processes, 89-121. Berlin: Mouton De Gruyter.

Whitney, William Dwight. 1881. On mixture in language. Transactions of the American Philosophical Association 12: 1-26.

Winford, Donald. 2003. An Introduction to Contact Linguistics. Oxford: Blackwell. Wohlgemuth, Jan. 20og. A Typology of Verbal Borrowings. Berlin: Mouton De Gruyter. 